\title{
Immunological and non-immunological effects of cytokines and chemokines in the pathogenesis of chronic Chagas disease cardiomyopathy
}

\author{
Edecio Cunha-Neto ${ }^{1,2,3} /^{+}$, Luciana G Nogueira ${ }^{1,3}$, Priscila C Teixeira ${ }^{1,3}$, Rajendranath Ramasawmy ${ }^{1,3}$, \\ Sandra A Drigo', Anna Carla Goldberg ${ }^{3}$, Simone G Fonseca ${ }^{1,2,3}$, Angelina M Bilate ${ }^{1,3}$, Jorge Kalil ${ }^{1,2,3}$ \\ 'Laboratório de Imunologia, Instituto do Coração, Hospital das Clínicas ²Disciplina de Imunologia Clínica e Alergia-LIM 60, Faculdade \\ de Medicina, Universidade de São Paulo, Av. Dr. Enéas de Carvalho Aguiar 44 Bloco 2/9o, 05403-001 São Paulo, SP, Brasil ${ }^{3}$ Instituto de \\ Investigação em Imunologia - INCT, São Paulo, SP, Brasil
}

The pathogenesis of Chagas disease cardiomyopathy (CCC) is not well understood. Since studies show that myocarditis is more frequent during the advanced stages of the disease, and the prognosis of CCC is worse than that of other dilated cardiomyopathies of non-inflammatory aetiology, which suggest that the inflammatory infiltrate plays a major role in myocardial damage. In the last decade, increasing evidence has shown that inflammatory cytokines and chemokines play a role in the generation of the inflammatory infiltrate and tissue damage. CCC patients have an increased peripheral production of the inflammatory Th1 cytokines IFN- $\gamma$ and TNF- $\alpha$ when compared to patients with the asymptomatic/indeterminate form. Moreover, Th1-T cells are the main producers of IFN- $\gamma$ and TNF- $\alpha$ and are frequently found in CCC myocardial inflammatory infiltrate. Over the past several years, our group has collected evidence that shows several cytokines and chemokines produced in the CCC myocardium may also have a non-immunological pathogenic effect via modulation of gene and protein expression in cardiomyocytes and other myocardial cell types. Furthermore, genetic polymorphisms of cytokine, chemokine and innate immune response genes have been associated with disease progression. We will review the molecular and immunological mechanisms of myocardial damage in human CCC in light of recent findings.

Key words: Chagas disease cardiomyopathy - cytokines - chemokines - gene polymorphism - energy metabolism

The most important clinical consequence of chronic Chagas disease is chronic Chagas disease cardiomyopathy (CCC), an inflammatory cardiomyopathy that develops in up to $30 \%$ of infected individuals. A significant proportion of those patients subsequently develop dilated cardiomyopathy with a fatal outcome. Heart failure of Chagasic aetiology has a worse prognosis and $50 \%$ lower survival rate than cardiomyopathies of noninflammatory aetiology, like ischemic and idiopathic dilated cardiomyopathy (Mady et al. 1994, Bocchi 1994, Bestetti \& Muccillo 1997). Vector transmission is under control in several regions and countries in Latin America; nevertheless, hundreds of thousands of patients already have CCC, not to mention numerous other individuals that currently have the indeterminate phase and still have the potential to develop cardiac symptoms. Although currently used of trypanocidal drugs are effective in the treatment of acute infection or recent infection in children from endemic areas, its efficacy in halting the progression of cardiac lesions has not been

Financial support: CNPq, FAPESP, MS

+Corresponding author: edecunha@usp.br

Received 20 April 2009

Accepted 18 May 2009 established (Marin-Neto et al. 2008). Available treatment for heart failure of CCC is the same supportive therapy used for other non-inflammatory aetiologies of heart failure. Our limited understanding of the pathogenesis of CCC may be the underlying reason for the lower survival of CCC patients. Thus, the need to find adequate treatment for $\mathrm{CCC}$ patients underscores the importance of studying CCC pathogenesis.

The pathogenesis of CCC is still matter of intense debate. The susceptibility factors that lead to $30 \%$ of individuals to develop CCC after Trypanosoma cruzi infection remain unknown. However, there are three main pathogenetic mechanisms to explain CCC development: cardiac dysautonomy, disorders of the microvascular circulation and inflammatory/immunological tissue damage. Since the majority of evidence indicates that the inflammatory infiltrate is a significant effector of heart tissue damage, we will review the effects of cytokines and chemokines in the pathogenesis of CCC. A recent review regarding other pathogenic mechanisms can be found in Marin-Neto et al. (2007).

\section{Pathogenesis: mononuclear inflammatory infiltrate}

The most striking histopathological feature in cardiac lesions of CCC patients is the presence of a diffuse myocarditis - albeit with focal aspects - with intense myocardial remodelling, fibrosis, cardiomyocyte hypertrophy and damage (Pereira-Barretto et al. 1986, Higuchi et al. 1987). In CCC, the inflammatory infiltrate is com- 
posed of macrophages $(50 \%), \mathrm{B}$ cells and $\mathrm{T}$ cells $(10 \%)$ and very few NK cells (Milei et al. 1992, Higuchi et al. 1993). Also, there is a $2: 1$ predominance of $\mathrm{CD} 8^{+}$over CD4+ T cells, with increased numbers of granzymepositive cells (Higuchi et al. 1993, Reis et al. 1993b) and restricted heterogeneity of $\mathrm{T}$ cell receptor variable alpha chain transcripts (Cunha-Neto et al. 1994), further indicating an antigen-driven inflammatory infiltrate. Several clinicopathological data suggest that the infiltrate plays a major role in the development and progression of the disease: (i) the mononuclear infiltrate is associated with local cardiomyocyte destruction and fibrosis, (ii) CCC presents a shorter survival and worse prognosis than cardiomyopathies of non-inflammatory aetiology, (iii) the frequency of myocarditis in endomyocardial biopsies correlates with the severity of the functional heart damage, being low among asymptomatic individuals with the indeterminate form, intermediate among patients with ECG abnormalities and very frequent (93\%) among CCC patients with dilated cardiomyopathy (Higuchi et al. 1987) and (iv) we found a positive correlation between the cellularity of the infiltrate and degree of ventricular dilation (unpublished observations) among hamsters chronically infected with $T$. cruzi. CD ${ }^{+}$ $\mathrm{T}$ cells recognizing $T$. cruzi antigens, such as cruzipain and FL-160, are also found in the CCC inflammatory infiltrate (Fonseca et al. 2005). Although it is difficult to locate $T$. cruzi nests in the myocardium of immunocompetent CCC patients, the presence of T. cruzi antigens and DNA has already been demonstrated (Higuchi et al. 1993, Jones et al. 1993) and an association between the persistence of parasite DNA and intense myocarditis has been reported (Benvenuti et al. 2008). On the other hand, $\mathrm{CD}^{+} \mathrm{T}$ cells can cross-react recognizing cardiac myosin the most abundant heart protein and T. cruzi protein B13 have also been recovered from the myocardium of CCC patients (Cunha-Neto et al. 1996, Abel et al. 1997, 2005, Iwai et al. 2005). Whatever the antigenic stimulus may be, it is long-lasting and maintains the local inflammatory infiltrate. Besides the observed tissue damage, histiocytes and endothelial cells display increased expression of HLA class I and class II molecules, ICAM and E-selectin, while cardiomyocytes express increased levels of HLA class I, which are markers normally found on cells in response to local production of inflammatory cytokines (Higuchi et al. 1993, Reis et al. 1993a).

\section{Cytokines and chemokines in the acute phase of $T$. cruzi infection}

Data from animal models show that inflammatory cytokines play a central role in acute $T$. cruzi infection. Shortly after the acute infection starts, $T$. cruzi components - including its DNA and membrane glycoconjugates - trigger innate immunity via Toll-like receptors 2 , 4 and 9 in macrophages and dendritic cells (Bafica et al. 2006). Upon activation, such cells secrete pro-inflammatory cytokines and chemokines, upregulate expression of co-stimulatory receptors and increase endocytosis and intracellular killing of parasites through release of reactive oxygen and nitrogen species. Pro-inflammatory cytokines, such as IL-1, IL-6, IL-12, IL-18, IL-27, and
TNF- $\alpha$ are promptly released, and further activate other inflammatory cells (Michailowsky et al. 2001, Bilate $\&$ Cunha-Neto 2008). Macrophages and dendritic cells that have endocytosed the parasite subsequently elicit a strong $\mathrm{T}$ cell and antibody response against $T$. cruzi. Interferon- $\gamma($ IFN- $\gamma)$ - producing T.cruzi - specific T cells are thus generated (Bilate \& Cunha-Neto 2008), and migrate together with other blood leukocytes to sites of $T$. cruzi-induced inflammation in response to chemokines such as CCL2, CCL3, CCL4, CCL5 and CXCL10, and participate in the immune response against the parasite (Teixeira et al. 2002). This inflammatory $\mathrm{T}$ cell and antibody response leads to control - but not complete elimination - of tissue and blood parasitism. On the other hand, the blockade of CCR5 with Met-RANTES significantly decreased the intensity of cardiac inflammatory infiltrate, suggesting that lymphocyte migration to the myocardium during acute infection is dependent on CCR5 ligands (Marino et al. 2004). The Syrian hamster model of $T$. cruzi infection reproduces the range of different outcomes of human Chagas disease (Ramirez et al. 1994, Bilate et al. 2003). During acute T. cruzi infection, hamsters displaying high cardiac parasitism also showed increased expression of TNF- $\alpha$, IFN- $\gamma$, IL-10 and CCL 3 mRNA, as well as acute phase signs such as weight loss, vomiting and diarrhoea while animals with low cardiac parasitism displayed a modest increase in cytokine/chemokine mRNA and no acute phase signs (Bilate \& Cunha-Neto 2008). Cardiac parasitism was apparently related to the increased expression of cytokines and chemokines, as well as to lower levels of $\alpha$-crystalin B chain (CRYAB) and increased expression of desmin and other structural proteins as suggested by proteomic analysis (Bilate \& Cunha-Neto 2008). On the other hand, animals with low parasitism displayed increased levels of CRYAB and unchanged levels of structural proteins. These results are in line with the idea that CRYAB isoforms may have a protective effect against cytoskeleton disruption and it has been reported that it exerts an inhibitory action on inflammatory cytokine production, although it cannot be excluded that the intense parasitism limits CRYAB expression in animals with acute phase signs and high parasitism. Acutely infected children have shown increased expression inflammatory cytokines, such as circulating IL-6 and TNF- $\alpha$ (Moretti et al. 2002) and have also displayed increased production of IFN- $\gamma$ by mononuclear cells (Samudio et al. 1998).

\section{Cytokines and chemokines in the chronic phase of T. cruzi infection}

Inflammatory cytokines are produced during the chronic phase of Chagas disease. Mononuclear cells increase their cytokine production, leading to increased plasma levels of TNF- $\alpha$ and IFN- $\gamma$, and are even detected in infected individuals with indeterminate forms of Chagas disease (Ribeirão et al. 2000, Abel et al. 2001, Ferreira et al. 2003, Talvani et al. 2004), which is probably in response to parasite persistent. The subset of patients that develop Chagas cardiomyopathy displays an array of immunological alterations consistent with an exacerbated Th1 immune response. CCC patients 
display increased circulating levels of TNF- $\alpha$ and CCL2 compared to individuals with the indeterminate form of Chagas disease, or those with ECG abnormalities alone but with no ventricular dysfunction (Ferreira et al. 2003, Talvani et al. 2004). Additionally, CCC patients show increased numbers of IFN- $\gamma$-producing $\mathrm{CCR}^{+} \mathrm{CXCR}^{+} \mathrm{CD}^{+}$and $\mathrm{CD}^{+}{ }^{+} \mathrm{T}$ cells, with reduced numbers of IL-10-producing and Fox $3^{+}$regulatory T cells (Abel et al. 2001, Gomes et al. 2003, 2005, Araujo et al. 2007) as compared to patients with the indeterminate form of Chagas disease.

The exacerbated Th1 response observed in the peripheral blood is reflected by the nature of the inflammatory infiltrate found in the myocardium of Chagas cardiomyopathy patients (Cunha-Neto et al. 2005). Mononuclear cells infiltrating $\mathrm{CCC}$ heart tissue express IFN- $\gamma$, TNF- $\alpha$ and IL- 6 , with lower levels of IL-2, IL-4 and IL-10 (Reis et al. 1993b, 1997, Abel et al. 2001). IL-7 and IL-15, which are cytokines that promote cell survival, expression in CCC heart tissue, is also found to be increased and may be the underlying reason for the predominance of $\mathrm{CD} 8^{+} \mathrm{T}$ cells, which express increased levels of IL-15R $\alpha$ and $\gamma_{c}$ chain receptor (Fonseca et al. 2007). Gene expression analysis of inflammatory mediators using real time-PCR allowed us to define the profile of inflammatory mediators in the CCC myocardium. We observed significantly increased expression of chemokine receptors CCR5, CXCR3 and CCR7 and their ligands, as well as IL-18 in the myocardium CCC patients, in comparison with samples from heart donors and non-inflammatory cardiomyopathy patients (Cunha-Neto et al. 2005 and our unpublished observations). For the first time, we observed a correlation between myocardial expression of a chemokine (in this case, a Th1 chemoattractant) and myocarditis intensity, thus corroborating our hypothesis that such chemokines contribute to the migration and accumulation of inflammatory cells in the myocardium CCC patients. We were able to detect mononuclear cells that express CXCR3, CCR5, CXCL9 and CCL5 in the myocardium of CCC patients using confocal immunofluorescence assays (unpublished observations). These results are consistent with the hypothesis that circulating $\mathrm{CCR}^{+}$ $\mathrm{CXCR}^{+} \mathrm{CCR}^{+}$Th1 inflammatory cells previously activated in the periphery via encounter with $T$. cruzi (Gomes et al. 2005), interact with CCR7 ligands in high endothelial venules in inflamed myocardium - where they may interact with soluble ligands for CCR5 and CXCR3 receptors (our unpublished data) and migrate into tissue. Local IL-18 production may push these cells into producing increased levels of IFN- $\gamma$ in a positive feedback loop. Also, IFN- $\gamma$-dependent chemokines, such as CCL5, CXCL9 and CXCL10, may increase the chemotactic signal and cause migration of more $\mathrm{CCR}^{+}$ $\mathrm{CXCR}^{+} \mathrm{T}$ lymphocytes to the myocardium. On the other hand, genes expressed by regulatory T cells (TGF- $\beta$ and Foxp3) or Th2 cells (IL-4 and IL-13) had reduced or undetectable expression in CCC heart tissue, suggesting that the intense Th1 inflammatory response in the myocardium of CCC patients occurs in the absence of other regulatory mechanisms.
Given the major role of Th1/inflammatory infiltrate in CCC heart, we tried to dampen the inflammatory response in an attempt to reduce the heart damage. Using the hamster model of dilated cardiomyopathy of human CCC, researchers found that blocking TNF- $\alpha$ with the soluble receptor Etanercept paradoxically worsened cardiac function (Bilate et al. 2007) in the absence of increased parasitism, direct drug toxicity, or increased myocarditis. These results suggest that there is a beneficial role for residual TNF- $\alpha$ signalling in Chagas disease cardiomyopathy and also suggests that TNF- $\alpha$ antagonism during the chronic phase of the T. cruzi infection worsens experimental cardiomyopathy, providing a cautionary note for cytokine-blocking intervention in human Chagas disease.

\section{Non-inflammatory effects of cytokines and media- tors on the myocardium}

Our group and others have found significant evidence of non-inflammatory cytokine and chemokine effects on cardiomyocytes and other myocardial cell types, in addition to the inflammatory effects of cytokines and chemokines. Significant IFN- $\gamma$ signalling was observed in the myocardium of CCC patients, including genes that are not ordinarily expressed by inflammatory cells. In vitro experiments have shown that IFN- $\gamma$ alone or in combination with CCL2 may induce profound changes in the cardiomyocyte gene expression program, including induction of atrial natriuretic factor and the hypertrophic gene expression program (Cunha-Neto et al. 2005). IL-18 and CCR7 ligands are upregulated in CCC myocardium and can induce cardiomyocyte hypertrophy and molecules involved in the fibrotic process (RiolBlanco et al. 2005, Sakai et al. 2006, Reddy et al. 2008). Transgenic mice overexpressing CCL2, TNF- $\alpha$ or IFN- $\gamma$ in the myocardium develop myocardial hypertrophy and ventricular dilation (Kolattukudy et al. 1998, Kubota et al. 2000, Reifenberg et al. 2007).

Inflammatory cytokines may also affect myocardial energy metabolism. Several heart disorders, especially those with ventricular dysfunction, are associated with reduced energy metabolism, especially when mitochondrial fatty acid or other energy metabolism enzymes are involved (Johnston et al. 1991, Carvajal \& Moreno-Sanchez 2003). Treatment of cardiomyocytes with IFN- $\gamma$ inhibited oxidative metabolism and ATP production (Wang et al. 1996). Additionally, IFN- $\gamma$ treatment reduces gene and protein expression of creatine kinase, which is responsible for translocation of mitochondrial ATP to the sarcoplasm in cultured human skeletal muscle cells (Kalovidouris et al. 1993). We observed that the myocardium of CCC patients displayed reduced expression of some key energy metabolism enzymes, including isoforms of creatine kinases, Krebs cycle enzymes and members of the ATP synthase complex, in comparison with the myocardium of patients from non-inflammatory cardiomyopathies and heart donors (unpublished observations), which could be partly due to IFN- $\gamma /$ inflammatory cytokine signalling. Using cDNA microarrays, our group also observed increased expression of genes 
encoding a number of proteins involved in oxidative phosphorylation and lipid catabolism in CCC myocardium as compared to idiopathic dilated cardiomyopathy or donor myocardium (Cunha-Neto et al. 2005). The increased expression of such genes could be a compensatory mechanism for cytoplasmic ATP depletion, as observed in mice genetically deficient for creatine kinases (Heddi et al. 1999, de Groof et al. 2001). cDNA microarray experiments in mice experimentally infected with $T$. cruzi showed changes in oxidative phosphorylation and depressed energy metabolism (Garg et al. 2003) and respiratory chain complexes with reduced ATP-generating capacity (Vyatkina et al. 2004). Thus, both IFN- $\gamma$ and T. cruzi infection can depress energy metabolism, thus reducing myocardial ATP generation, which has potential consequences for myocardial contractility, electric conduction and rhythm.

We can thus hypothesise that, apart from the direct inflammatory damage, non-immunological effects of several mediators locally produced in the myocardium, such as IFN- $\gamma$, TNF- $\alpha$, IL-18, CCL2 and CCL21, may play a significant pathogenic role in $\mathrm{CCC}$, by modulating gene and protein expression of cardiomyocytes and fibrocytes in pathways essential for the development of CCC, such as hypertrophy, fibrosis and energy metabolism. It is clear that $\mathrm{T}$ cell migration to the myocardium and non-immunological effects of chemokines and other me- diators are prime candidates for intervention in Chagas disease. Understanding the importance of these pathways in the pathogenesis may be instrumental for the development of more adequate therapy for chronic CCC.

\section{Genetics and differential evolution to CCC}

Mechanisms underlying differential progression to $\mathrm{CCC}$ are still incompletely understood. Familial aggregation of CCC has been described (Zicker et al. 1990), suggesting that there might be a genetic component to disease susceptibility. This is also supported by the fact that only one third of $T$. cruzi-infected individuals develop CCC. Given the importance of inflammatory mechanisms for CCC pathogenesis, genetic susceptibility to CCC may result from functionally relevant genetic polymorphisms that lead to variations in the intensity of the innate or acquired immune response and in inflammatory cytokines and chemokines involved in the pathogenesis of the disease. During the past few years, our group has shown associations between SNPs in genes such as CCL2, BAT1 (an inhibitor of inflammatory cytokines), Lymphotoxin- $\alpha$, NFKBIL1 (potential inhibitor of NFKB) and MAL/TIRAP (an adaptor protein involved in the TLR2 and TLR4 signalling pathway) with CCC when compared with the indeterminate group (Ramasawmy et al. 2006a, b, 2008, 2009). Furthermore, we have shown that severe CCC patients carrying the

TABLE

Host genetic polymorphisms studied in Chagas disease

\begin{tabular}{|c|c|c|c|}
\hline Gene & Polymorphism & Susceptibility/association & Reference \\
\hline HLA & several, class I and II & contradictory & $\begin{array}{c}\text { Deghaide et al. 1998, Fernandez-Mestre et al. } \\
\text { (1998), Colorado et al. (2000), Fae et al. (2000), } \\
\text { Layrisse et al. (2000), Nieto et al. (2000), } \\
\text { Cruz-Robles et al. (2004) }\end{array}$ \\
\hline$\beta$ Cardiac myosin heavy chain & (CATT)n & negative & Fae et al. (2000) \\
\hline$C C L 2 / M C P 1$ & -2518 & $\mathrm{CCC}$ & Ramasawmy et al. (2006a) \\
\hline CCR5 & +53029 & $\mathrm{CCC}$ & Calzada et al. (2001a) \\
\hline$N R A M P 1$ & $\begin{array}{c}\text { 5'(GT)n, -236 C-->T, D543N, } \\
\text { 3'UTR deletion }\end{array}$ & negative & Calzada et al. (2001b) \\
\hline NOS2 & $($ CCTTT $) n$ & negative & Calzada et al. (2002) \\
\hline$T N F-\alpha$ & $-308,-238, \mathrm{TNFa}$ & negative & Beraun et al. 1998, Drigo et al. (2007) \\
\hline$T N F-\alpha$ & -308 & $\mathrm{CCC}$ & Rodriguez-Perez et al. (2005) \\
\hline$T N F-\alpha$ & $-308, \mathrm{TNFa}$ & $\begin{array}{l}\text { progression to death/ } \\
\text { heart transplant }\end{array}$ & Drigo et al. (2006) \\
\hline LTA & $+80,+252$ & $\mathrm{CCC}$ & Ramasawmy et al. (2007) \\
\hline$B A T-1$ & $-22,348$ & $\mathrm{CCC}$ & Ramasawmy et al. (2006b) \\
\hline$N F k B I L-1$ & $-62,-262$ & $\mathrm{CCC}$ & Ramasawmy et al. (2008) \\
\hline$I L 1 B$ & $-31,+3954,+5810$ & $\mathrm{CCC}$ & Flórez et al. (2006) \\
\hline$I L-10$ & -1082 & $\mathrm{CCC}$ & Costa et al. (2009) \\
\hline$I L-12 B$ & +1188 & $\mathrm{CCC}$ & Zafra et al. (2007) \\
\hline$T L R 1,2,4,5,9$ & & negative & Ramasawmy et al. (2009), \\
\hline$M A L / T I R A P$ & S180L & $\mathrm{CCC}$ & Ramasawmy et al. (2009), \\
\hline$A C E$ & $\mathrm{I} / \mathrm{D}$ & negative & Cuoco et al. 2005, Pascuzzo-Lima et al. (2009) \\
\hline
\end{tabular}


high TNF- $\alpha$ expresser genotype have shorter survival (Drigo et al. 2006). The Table shows all host genetic polymorphisms in Chagas disease published to date. The search for associations between candidate genes with the development of CCC has been focused on genes involved in immune response and inflammation. The association of SNPs in genes such as IL1B, TNF, LTA, IL10, IL12B, MAL/TIRAP, CCL2 and CCR5 with the progression to $\mathrm{CCC}$ is in accordance to what is expected, especially when the importance of migration of innate immune cells, inflammatory cytokines and chemokinedependent migration in the pathogenesis of CCC is considered. As in with every multi-faceted disease, the input of each gene involved in the development of CCC is expected to be very small (1-10\% of the susceptibility). However, identification of key genes and potent genetic combinations coupled with environmental factors may lead to the identification of T. cruzi-infected individuals that will progress to CCC. SNPs in other genes such as those involved in cardiovascular diseases (heart failure and ischemic heart disease) also need to be screened in T. cruzi-infected individuals. The first candidate cardiovascular polymorphism (ACE I/D polymorphism) showed no association with progression to CCC. The pace of discovery has been slow; in the 12 years since the first publication, in 1998, 19 loci were studied, and only 10 showed any association with disease progression. Better success in identification of genetic markers in Chagas disease will only come when the sample size exceeds the ones previously used in the past CCC studies. Large sample size (on the order of 1000's for each clinical group) will allow us to use high-throughput SNP detection to define a pattern of genetic susceptibility in the development of CCC, which may thus draw new modalities for prognosis and appropriate treatment.

\section{ACKNOWLEDGMENTS}

To Dr. Daniela S. Rosa, for critically reading the manuscript.

\section{REFERENCES}

Abel LC, Iwai LK, Viviani W, Bilate AM, Fae KC, Ferreira RC, Goldberg AC, Juliano L, Juliano MA, Ianni B, Mady C, Gruber A, Hammer J, Sinigaglia F, Kalil J, Cunha-Neto E 2005. T cell epitope characterization in tandemly repetitive Trypanosoma cruzi B13 protein. Microbes Infect 7: 1184-1195.

Abel LC, Kalil J, Cunha Neto E 1997. Molecular mimicry between cardiac myosin and Trypanosoma cruzi antigen B13: identification of a B13-driven human $\mathrm{T}$ cell clone that recognizes cardiac myosin. Braz J Med Biol Res 30: 1305-1308.

Abel LC, Rizzo LV, Ianni B, Albuquerque F, Bacal F, Carrara D, Bocchi EA, Teixeira HC, Mady C, Kalil J, Cunha-Neto E 2001. Chronic Chagas' disease cardiomyopathy patients display an increased IFN-gamma response to Trypanosoma cruzi infection. J Autoimmun 17: 99-107.

Araujo FF, Gomes JA, Rocha MO, Williams-Blangero S, Pinheiro VM, Morato MJ, Correa-Oliveira R 2007. Potential role of CD4+CD25 HIGH regulatory T cells in morbidity in Chagas disease. Front Biosci 12: 2797-2806.

Bafica A, Santiago HC, Goldszmid R, Ropert C, Gazzinelli RT, Sher A 2006. Cutting edge: TLR9 and TLR2 signaling together account for MyD88-dependent control of parasitemia in Trypanosoma cruzi infection. J Immunol 177: 3515-3519.
Benvenuti LA, Roggerio A, Freitas HF, Mansur AJ, Fiorelli A, Higuchi ML 2008. Chronic American trypanosomiasis: parasite persistence in endomyocardial biopsies is associated with highgrade myocarditis. Ann Trop Med Parasitol 102: 481-487.

Beraun Y, Nieto A, Collado MD, Gonzalez A, Martin J 1998. Polymorphisms at tumor necrosis factor (TNF) loci are not associated with Chagas' disease. Tissue Antigens 52: 81-83.

Bestetti RB, Muccillo G 1997. Clinical course of Chagas' heart disease: a comparison with dilated cardiomyopathy. Int J Cardiol 60: 187-193.

Bilate AM, Cunha-Neto E 2008. Chagas disease cardiomyopathy: current concepts of an old disease. Rev Inst Med Trop São Paulo 50: 67-74.

Bilate AM, Salemi VM, Ramires FJ, de Brito T, Russo M, Fonseca SG, Faé KC, Martins DG, Silva AM, Mady C, Kalil J, CunhaNeto E 2007. TNF blockade aggravates experimental chronic Chagas disease cardiomyopathy. Microbes Infect 9: 1104-1113.

Bilate AM, Salemi VM, Ramires FJ, de Brito T, Silva AM, Umezawa ES, Mady C, Kalil J, Cunha-Neto E 2003. The Syrian hamster as a model for the dilated cardiomyopathy of Chagas' disease: a quantitative echocardiographical and histopathological analysis, Microbes Infect 5: 1116-1124.

Bilate AM, Teixeira PC, Ribeiro SP, Brito T, Silva AM, Russo M, Kalil J, Cunha-Neto E 2008. Distinct outcomes of Trypanosoma cruzi infection in hamsters are related to myocardial parasitism, cytokine/chemokine gene expression and protein expression profile. J Infect Dis 198: 614-623.

Bocchi EA 1994. Update on indications and results of the surgical treatment of heart failure. Arq Bras Cardiol 63: 523-530

Calzada JE, Lopez-Nevot MA, Beraun Y, Martin J 2002. No evidence for association of the inducible nitric oxide synthase promoter polymorphism with Trypanosoma cruzi infection. Tissue Antigens 59: 316-319.

Calzada JE, Nieto A, Beraun Y, Martin J 2001a. Chemokine receptor CCR5 polymorphisms and Chagas' disease cardiomyopathy. Tissue Antigens 58: 154-158.

Calzada JE, Nieto A, Lopez-Nevot MA, Martin J 2001b. Lack of association between NRAMP1 gene polymorphisms and Trypanosoma cruzi infection. Tissue Antigens 57: 353-357.

Carvajal K, Moreno-Sanchez R 2003. Heart metabolic disturbances in cardiovascular diseases. Arch Med Res 34: 89-99.

Colorado IA, Acquatella H, Catalioti F, Fernandez MT, Layrisse Z 2000. HLA class II DRB1, DQB1, DPB1 polymorphism and cardiomyopathy due to Trypanosoma cruzi chronic infection. Hum Immunol 61: 320-325.

Costa GC, da Costa Rocha MO, Moreira PR, Menezes CA, Silva MR, Gollob KJ, Dutra WO 2009. Functional IL-10 gene polymorphism is associated with Chagas disease cardiomyopathy. J Infect Dis 199: 451-454.

Cruz-Robles D, Reyes PA, Monteon-Padilla VM, Ortiz-Muniz AR, Vargas-Alarcon G 2004. MHC class I and class II genes in Mexican patients with Chagas disease. Hum Immunol 65: 60-65.

Cunha-Neto E, Coelho V, Guilherme L, Fiorelli A, Stolf N, Kalil J 1996. Autoimmunity in Chagas' disease. Identification of cardiac myosin-B13 Trypanosoma cruzi protein crossreactive T cell clones in heart lesions of a chronic Chagas' cardiomyopathy patient. J Clin Invest 8: 1709-1712.

Cunha-Neto E, Dzau VJ, Allen PD, Stamatiou D, Benvenutti L, Higuchi ML, Koyama NS, Silva JS, Kalil J, Liew CC 2005. Cardiac 
gene expression profiling provides evidence for cytokinopathy as a molecular mechanism in Chagas' disease cardiomyopathy. Am J Pathol 167: 305-313.

Cunha-Neto E, Moliterno R, Coelho V, Guilherme L, Bocchi E, Higuchi Mde L, Stolf N, Pileggi F, Steinman L, Kalil J 1994. Restricted heterogeneity of $\mathrm{T}$ cell receptor variable alpha chain transcripts in hearts of Chagas' disease cardiomyopathy patients. Parasite Immunol 16: 171-179.

Cuoco MA, Pereira AC, de Freitas HF, de Fátima Alves da Mota G, Fukushima JT, Krieger JE, Mansur AJ 2005. Angiotensin-converting enzyme gene deletion polymorphism modulation of onset of symptoms and survival rate of patients with heart failure. Int J Cardiol 99: 97-103.

Deghaide NH, Dantas RO, Donadi EA 1998. HLA class I and II profiles of patients presenting with Chagas' disease. Dig Dis Sci 43: 246-252.

de Groof AJ, Smeets B, Groot Koerkamp MJ, Mul AN, Janssen EE, Tabak HF, Wieringa B 2001. Changes in mRNA expression profile underlie phenotypic adaptations in creatine kinase-deficient muscles. FEBS Lett 506: 73-78.

Drigo SA, Cunha-Neto E, Ianni B, Cardoso MR, Braga PE, Fae KC, Nunes VL, Buck P, Mady C, Kalil J, Goldberg AC 2006. TNF gene polymorphisms are associated with reduced survival in severe Chagas' disease cardiomyopathy patients. Microbes Infect 8: 598-603.

Drigo SA, Cunha-Neto E, Ianni B, Mady C, Fae KC, Buck P, Kalil J, Goldberg AC 2007. Lack of association of tumor necrosis factor-a polymorphisms with Chagas disease in Brazilian patients. Immunol Lett 108: 109-111.

Fae KC, Drigo SA, Cunha-Neto E, Ianni B, Mady C, Kalil J, Goldberg AC 2000. HLA and beta-myosin heavy chain do not influence susceptibility to Chagas disease cardiomyopathy. Microbes Infect 2: 745-751.

Fernandez-Mestre MT, Layrisse Z, Montagnani S, Acquatella H, Catalioti F, Matos M, Balbas O, Makhatadze N, Dominguez E, Herrera F, Madrigal A 1998. Influence of the HLA class II polymorphism in chronic Chagas' disease. Parasite Immunol 20: 197-203.

Ferreira RC, Ianni BM, Abel LC, Buck P, Mady C, Kalil J, CunhaNeto E 2003. Increased plasma levels of tumor necrosis factor-a in asymptomatic/"indeterminate" and Chagas disease cardiomyopathy patients. Mem Inst Oswaldo Cruz 98: 407-411.

Flórez O, Zafra G, Morillo C, Martín J, González CI 2006. Interleukin-1 gene cluster polymorphism in Chagas disease in a Colombian case-control study. Hum Immunol 67: 741-748.

Fonseca SG, Moins-Teisserenc H, Clave E, Ianni B, Nunes VL, Mady C, Iwai LK, Sette A, Sidney J, Marin ML, Goldberg AC, Guilherme L, Charron D, Toubert A, Kalil J, Cunha-Neto E 2005. Identification of multiple HLA-A*0201-restricted cruzipain and FL-160 CD8+ epitopes recognized by $\mathrm{T}$ cells from chronically Trypanosoma cruzi-infected patients. Microbes Infect 7: 688-697.

Fonseca SG, Reis MM, Coelho V, Nogueira LG, Monteiro SM, Mairena EC, Bacal F, Bocchi E, Guilherme L, Zheng XX, Liew FY, Higuchi ML, Kalil J, Cunha-Neto E 2007. Locally produced survival cytokines IL-15 and IL-7 may be associated to the predominance of CD8+ T cells at heart lesions of human chronic Chagas disease cardiomyopathy. Scand J Immunol 66: 362-371.

Garg N, Popov VL, Papaconstantinou J 2003. Profiling gene transcription reveals a deficiency of mitochondrial oxidative phosphorylation in Trypanosoma cruzi-infected murine hearts: implications in chagasic myocarditis development. Biochim Biophys 1638: 106-20.

Gomes JA, Bahia-Oliveira LM, Rocha MO, Busek SC, Teixeira MM, Silva JS, Correia-Oliveira R 2005. Type 1 chemokine receptor ex- pression in Chagas' disease correlates with morbidity in cardiac patients. Infect Immun 73: 7960-7966.

Gomes JA, Bahia-Oliveira LM, Rocha MO, Martins-Filho OA, Gazzinelli G, Correa-Oliveira R 2003. Evidence that development of severe cardiomyopathy in human Chagas' disease is due to a Th1-specific immune response. Infect Immun 71: 1185-1193.

Heddi A, Stepien G, Benke PJ, Wallace DC 1999. Coordinate induction of energy gene expression in tissues of mitochondrial disease patients. J Biol Chem 274: 22968-22976.

Higuchi ML, De Morais CF, Pereira Barreto AC, Lopes EA, Stolf N, Bellotti G, Pillegi F 1987. The role of active myocarditis in the development of heart failure in chronic Chagas' disease: a study based on endomyocardial biopsies. Clin Cardiol 10: 665-670.

Higuchi ML, Gutierrez PS, Aiello VD, Palomino S, Bocchi E, Kalil J, Bellotti G, Pileggi F 1993. Immunohistochemical characterization of infiltrating cells in human chronic chagasic myocarditis: comparison with myocardial rejection process. Virchows Arch A Pathol Anat Histopathol 423: 157-160.

Iwai LK, Juliano MA, Juliano L, Kalil J, Cunha-Neto E 2005. T-cell molecular mimicry in Chagas disease: identification and partial structural analysis of multiple cross-reactive epitopes between Trypanosoma cruzi $\mathrm{B} 13$ and cardiac myosin heavy chain. $J$ Autoimmun 24: 111-117.

Johnston DL, Lewandowski ED 1991. Fatty acid metabolism and contractile function in the reperfused myocardium. Multinuclear NMR studies of isolated rabbit hearts. Circ Res 68: 714-725.

Jones EM, Colley DG, Tostes S, Lopes ER, Vnencak-Jones CL, McCurley TL 1993. Amplification of a Trypanosoma cruzi DNA sequence from inflammatory lesions in human chagasic cardiomyopathy. Am J Trop Med Hyg 48: 348-357.

Kalovidouris AE, Plotkin Z, Graesser D 1993. Interferon-g inhibits proliferation, differentiation and creatine kinase activity of cultured human muscle cells. II. A possible role in myositis. J Rheumatol 20: 1718-23.

Kolattukudy PE, Quach T, Bergese S, Breckenridge S, Hensley J, Altschuld R, Gordillo G, Klenotic S, Orosz C, Parker-Thornburg J 1998. Myocarditis induced by targeted expression of the MCP-1 gene in murine cardiac muscle. Am J Pathol 152: 101-111.

Kubota T, Bounoutas GS, Miyagishima M, Kadokami T, Sanders VJ, Bruton C, Robbins PD, McTiernan CF, Feldman AM 2000. Soluble tumor necrosis factor receptor abrogates myocardial inflammation but not hypertrophy in cytokine-induced cardiomyopathy. Circulation 101: 2518-2525.

Layrisse Z, Fernandez MT, Montagnani S, Matos M, Balbas O, Herrera F, Colorado IA, Catalioti F, Acquatella H 2000. HLA-C(*)03 is a risk factor for cardiomyopathy in Chagas disease. Hum Immunol 61: 925-929.

Mady C, Cardoso RH, Barretto AC, da Luz PL, Bellotti G, Pileggi F 1994. Survival and predictors of survival in patients with congestive heart failure due to Chagas' cardiomyopathy. Circulation 90: 3098-3102.

Marin-Neto JA, Cunha-Neto E, Maciel BC, Simoes MV 2007. Pathogenesis of chronic Chagas heart disease. Circulation 115: 1109-1123.

Marin-Neto JA, Rassi A Jr, Morillo CA, Avezum A, Connolly SJ, Sosa-Estani S, Rosas F, Yusuf S 2008. Rationale and design of a randomized placebo-controlled trial assessing the effects of etiologic treatment in Chagas' cardiomyopathy: the Benznidazole Evaluation For Interrupting Trypanosomiasis (BENEFIT). Am Heart J 156: 37-43.

Marino AP, da Silva A, dos Santos P, Pinto LM, Gazzinelli RT, Teixeira MM, Lannes-Vieira J 2004. Regulated on activation, nor- 
mal T cell expressed and secreted (RANTES) antagonist (MetRANTES) controls the early phase of Trypanosoma cruzi-elicited myocarditis. Circulation 110: 1443-1449.

Michailowsky V, Silva NM, Rocha CD, Vieira LQ, Lannes-Vieira J, Gazzinelli RT 2001. Pivotal role of interleukin-12 and interferon$\mathrm{g}$ axis in controlling tissue parasitism and inflammation in the heart and central nervous system during Trypanosoma cruzi infection. Am J Pathol 159: 1723-1733.

Milei J, Storino R, Fernandez Alonso G, Beigelman R, Vanzulli S, Ferrans VJ 1992. Endomyocardial biopsies in chronic chagasic cardiomyopathy. Immunohistochemical and ultrastructural findings. Cardiology 80: 424-437.

Moretti E, Basso B, Cervetta L, Brigada A, Barbieri G 2002. Patterns of cytokines and soluble cellular receptors in the sera of children with acute Chagas' disease. Clin Diagn Lab Immunol 9: 1324-1327.

Nieto A, Beraun Y, Collado MD, Caballero A, Alonso A, Gonzalez A, Martin J 2000. HLA haplotypes are associated with differential susceptibility to Trypanosoma cruzi infection. Tissue Antigens 55: 195-198.

Pascuzzo-Lima C, Mendible JC, Bonfante-Cabarcas RA 2009. Angiotensin-converting enzyme insertion/deletion gene polymorphism and progression of Chagas' cardiomyopathy. Rev Esp Cardiol 62: 320-322.

Pereira Barretto AC, Mady C, Arteaga-Fernandez E, Stolf N, Lopes EA, Higuchi ML, Bellotti G, Pileggi F 1986. Right ventricular endomyocardial biopsy in chronic Chagas' disease. Am Heart $J$ 111: $307-312$.

Ramasawmy R, Cunha-Neto E, Fae, KC, Borba SCP, Teixeira PC, Ferreira SCP, Goldberg AC, Ianni B, Mady C, Kalil J 2009. Heterozygosity for the variant S180L of the adaptor protein MAL/TIRAP in the TLR-pathway is associated with lower risk of developing chronic Chagas cardiomyopathy. J Infect, in press.

Ramasawmy R, Cunha-Neto E, Fae KC, Martello FG, Müller NG, Cavalcanti VL, Ianni B, Mady C, Kalil J, Goldberg AC 2006a. The monocyte chemoattractant protein-lgene polymorphism is associated with cardiomyopathy in human Chagas disease. Clin Infect Dis 43: 305-311.

Ramasawmy R, Cunha-Neto E, Fae KC, Muller NG, Cavalcanti VL, Drigo SA, Ianni B, Mady C, Kalil J, Goldberg AC 2006b. BAT1, a putative anti-inflammatory gene, is associated with chronic Chagas cardiomyopathy. J Infect Dis 193: 1394-1399.

Ramasawmy R, Fae KC, Cunha-Neto E, Borba SC, Ianni B, Mady C, Goldberg AC, Kalil J 2008. Variants in the promoter region of IKBL/NFKBIL1 gene may mark susceptibility to the development of chronic Chagas' cardiomyopathy among Trypanosoma cruzi-infected individuals. Mol Immunol 45: 283-288.

Ramasawmy R, Fae KC, Cunha-Neto E, Muller NG, Cavalcanti VL, Ferreira RC, Drigo SA, Ianni B, Mady C, Goldberg AC, Kalil J 2007. Polymorphisms in the gene for lymphotoxin-a predispose to chronic Chagas cardiomyopathy. J Infect Dis 196: 1836-1843.

Ramirez LE, Lages-Silva E, Soares-Junior JM, Chapadeiro E 1994. The hamster (Mesocricetus auratus) as experimental model in Chagas' disease: parasitological and histopathological studies in acute and chronic phases of Trypanosoma cruzi infection. Rev Soc Bras Med Trop 27: 163-169.

Reddy VS, Harskamp RE, van Ginkel MW, Calhoon J, Baisden CE, Kim IS, Valente AJ, Chandrasekar B 2008. Interleukin-18 stimulates fibronectin expression in primary human cardiac fibroblasts via PI3K-Akt-dependent NF-kappaB activation. J Cell Physiol 215: 697-707.

Reifenberg K, Lehr HA, Torzewski M, Steige G, Wiese E, Kupper I, Becker C, Ott S, Nusser P, Yamamura K, Rechtsteiner G,
Warger T, Pautz A, Kleinert H, Schmidt A, Pieske B, Wenzel P, Münzel T, Löhler J 2007. Interferon-g induces chronic active myocarditis and cardiomyopathy in transgenic mice. $\mathrm{Am} \mathrm{J}$ Pathol 171: 463-472.

Reis DD, Jones EM, Tostes S, Lopes ER, Chapadeiro E, Gazzinelli G, Colley DG, McCurley TL 1993a. Expression of major histocompatibility complex antigens and adhesion molecules in hearts of patients with chronic Chagas' disease. Am J Trop Med Hyg 49: 192-200.

Reis DD, Jones EM, Tostes S Jr, Lopes ER, Gazzinelli G, Colley DG, McCurley TL 1993b. Characterization of inflammatory infiltrates in chronic chagasic myocardial lesions: presence of tumor necrosis factor-a+ cells and dominance of granzyme A+, CD8+ lymphocytes. Am J Trop Med Hyg 48: 637-644.

Reis MM, Higuchi Mde L, Benvenuti LA, Aiello VD, Gutierrez PS, Bellotti G, Pileggi F 1997. An in situ quantitative immunohistochemical study of cytokines and IL-2R+ in chronic human chagasic myocarditis: correlation with the presence of myocardial Trypanosoma cruzi antigens. Clin Immunol Immunopathol 83: 165-172.

Ribeirão M, Pereira-Chioccola VL, Renia L, Augusto Fragata Filho A, Schenkman S, Rodrigues MM 2000. Chagasic patients develop a type 1 immune response to Trypanosoma cruzi transsialidase. Parasite Immunol 22: 49-53.

Riol-Blanco L, Sanchez-Sanchez N, Torres A, Tejedor A, Narumiya S, Corbi AL, Sánchez-Mateos P, Rodríguez-Fernández JL 2005. The chemokine receptor CCR7 activates in dendritic cells two signaling modules that independently regulate chemotaxis and migratory speed. J Immunol 174: 4070-4080.

Rodriguez-Perez JM, Cruz-Robles D, Hernandez-Pacheco G, PerezHernandez N, Murguia LE, Granados J, Reyes PA, Vargas-Alarcón G 2005. Tumor necrosis factor-a promoter polymorphism in Mexican patients with Chagas' disease. Immunol Lett 98: 97-102.

Sakai N, Wada T, Yokoyama H, Lipp M, Ueha S, Matsushima K, Kaneko S 2006. Secondary lymphoid tissue chemokine (SLC/ CCL21)/CCR7 signaling regulates fibrocytes in renal fibrosis. Proc Natl Acad Sci USA 103: 14098-14103.

Samudio M, Montenegro-James S, de Cabral M, Martinez J, Rojas de Arias A, Woroniecky O, James MA 1998. Differential expression of systemic cytokine profiles in Chagas' disease is associated with endemicity of Trypanosoma cruzi infections. Acta Trop 69: 89-97.

Talvani A, Rocha MO, Barcelos LS, Gomes YM, Ribeiro AL, Teixeira MM 2004. Elevated concentrations of CCL2 and tumor necrosis factor-a in chagasic cardiomyopathy. Clin Infect Dis 38: 943-950.

Teixeira MM, Gazzinelli RT, Silva JS 2002. Chemokines, inflammation and Trypanosoma cruzi infection. Trends Parasitol 18: 262-265.

Vyatkina G, Bhatia V, Gerstner A, Papaconstantinou J, Garg N 2004. Impaired mitochondrial respiratory chain and bioenergetics during chagasic cardiomyopathy development. Biochim Biophys Acta 1689: 162-173.

Wang D, McMillin JB, Bick R, Buja LM 1996. Response of the neonatal rat cardiomyocyte in culture to energy depletion: effects of cytokines, nitric oxide and heat shock proteins. Lab Invest 75: 809-818.

Zafra G, Morillo C, Martin J, Gonzalez A, Gonzalez CI 2007. Polymorphism in the 3' UTR of the IL12B gene is associated with Chagas' disease cardiomyopathy. Microbes Infect 9: 1049-1052.

Zicker F, Smith PG, Netto JC, Oliveira RM, Zicker EM 1990. Physical activity, opportunity for reinfection and sibling history of heart disease as risk factors for Chagas' cardiopathy. Am J Trop Med Hyg 43: 498-505. 